\title{
血液透析患者の白内障に対する人エレンズ挿入術の成績
}

\author{
市川一夫 内藤尚久 中嶋潤稲垣 豊* \\ 天 野 泉* \\ 中京病院眼科 同透析科*
}

(昭和 61 年 10 月 27 日受付)

key words：血液透析, 白内障, 人エレンズ

〈要旨〉

1983 年 9 月から 1986 年 4 月までに, 当科にて計画的水晶体囊外摘出術ならびに人エレンズ插入術 (ECCE $+I O L) を$ 施行した透析患者 8 例 13 眼と当科における伊東ら ${ }^{2)}$ の水晶体全摘術 (ICCE) の結果を比較検討した.

$E C C E+I O L$ は, 経過観察期間 2 か月〜 2 年 9 か月平均 1 年 3 か月において, 術後視力に関して ICCE 法と比較し て問題なく, ICCE 法後無水晶体眼者としての handicap を考えると, 透析患者における白内障手術としても ECCE+ IOL はよりよい方法と思われた。

\section{Results of Intraocular lens implantation in hemodialysis patients}

Kazuo Ichikawa, M.D., Naohisa Naito, M.D., Jun Nakashima, M.D., Yutaka Inagaki, M.D.*, Izumi Amano, M.D.*

Departments of Ophthalmology and Dialysis Therapy*, Chukyo Hospital

There are several reports, including those by Ito et al. of our own hospital, on the results of cataract operations (intracapsular cataract extraction: ICCE) in patients undergoing hemodialysis. However, hemodialysis patients are already socially handicapped, and there would be many problems if they are burdened with the additional handicaps of aphakic patients. The results of planned extracapsular cataract extraction ( $p-E C C E)$ and intraocular lens implantation (IOL) in such patients are reported.

P-ECCE and IOL were performed in eight cases, i. e., in 13 eyes of hemodialysis patients with indications for cataract operations, who requested implantation IOL, in the period from September, 1983 to April, 1986.

No abnormal findings were noted in the postoperative course which has ranged from a minimum of 2 months to a maximum of 2 years and 9 months, paticularly compared with the natural course of the aphakic eye thus far. Preoperative visual acuity was 0.1 the light sense meaning and postoperative acuity was 0.1 to 1.2 , all the cases having improved. Compared with the report of Ito et al. in 1984 on ICCE, p-EECE and IOL are considered to be a safe operations not at all less advantageous than the former ICCE, and especially advantageous with respect to the daily life activities of patients with dialysis who have handicaps.

\section{緒言}

透析による白内障の進行が報告されている一方，透析 患者の平均余命の延長及び高齢者の透析患者の増加によ り, 白内障手術を必要とする透析患者が増加する傾向に ある. 高齢化社会を迎え今後この傾向は一層䫓著になる ものと思われる. 透析患者の白内障手術の成績について は当院の伊東ら ${ }^{2)}$ もらのを含め 2,3 の報告があるが, いづれも水晶体全摘出術についての報告である. 透析患

市川 一夫 中京病院眼科

干 457 名古屋市南区三条町 1-23（052-691-7151）
者にはすでに handicap をもっており，その上に人工的 無水晶体眼者としての handicap が加わることを考元る と, 人エレンズ挿入術が安全に施行できるものならばよ り望ましい.

今回我々は，透析患者に計画的水晶体囊外摘出術十人 エレンズ插入術 $(\mathrm{ECCE}+\mathrm{IOL})$ を施行し，当院に扔ける 過去の伊東ら ${ }^{2}$ の水晶体全摘出術 (ICCE) と比較検討し $\mathrm{ECCE}+\mathrm{IOL}$ は ICCE 上り優れるとも劣らない手術法で あるとの成績を得たので報告する。 


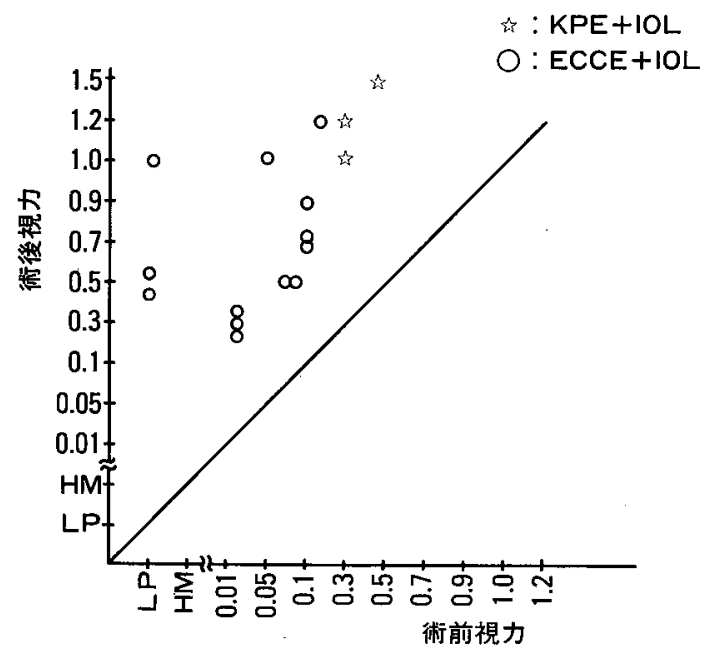

図 1 術前および術後視力

$\mathrm{KPE}$ : 超音波水晶体乳化吸引術 $\mathrm{ECCE}$ : 水晶体霬外摘 出術 ICCE : 水晶体囊内摘出術 IOL : 眼内レンズ

\section{対象}

対象は 1983 年 9 月から 1986 年 4 月までに当科にて白 内障手術を施行した透析患者 14 例 23 眼のうち ECCE+ IOL を施行した 8 例 13 眼である. 年齢は 60 歳以上のも ので, 透析患者における人エレンズの安全性について説 明し，希望するものを対象とした。

方法

透析方法は表 1 に示したごとくであり，使用へパリン を半量とした以外とくに通常の透析と変更しなかった。 手術は透析日と透析日の間に施行した。

手術は，原則として計画的水晶体囊外摘出術十人工レ ンズ授入術 (ECCE+IOL) を施行した. ECCE（四面切 開法）は，結膜円蓋部を基底とする結膜切開後通常の $\mathrm{ECCE}$ より少し強めに止血し, 強角膜切開したのち, can opener technique にてほほ网形に前囊切開，圧出法にて 水晶体核摘出，8-0 silk にて 3 針仮縫合, Cooper \& Cavitron 社の 6500 Irrigation-Aspiration System にて 水晶体残留皮質を吸引除去, Helon を使用して囊内に人 エレンズを移植した，強角膜創は 10-0 nylon にて 5 針 単単埋没縫合し，結膜は熱凝固にて接着した。1例 2 眼 は，後にのべる理由から前房レンズを移植した。

\section{結果}

術前の血液検查所見の結果は, 表 1 のごとくであった. 出血時間は若干の延長を認めるものの全例 5 分以内で あった。表 1 ( )内に示したのは当院に打ける伊東ら の水晶体全摘術の報告例のものであるが, 両者に差は認 めなかった。

手術時間は, 23 分から 42 分平均 30 分であった. 術中

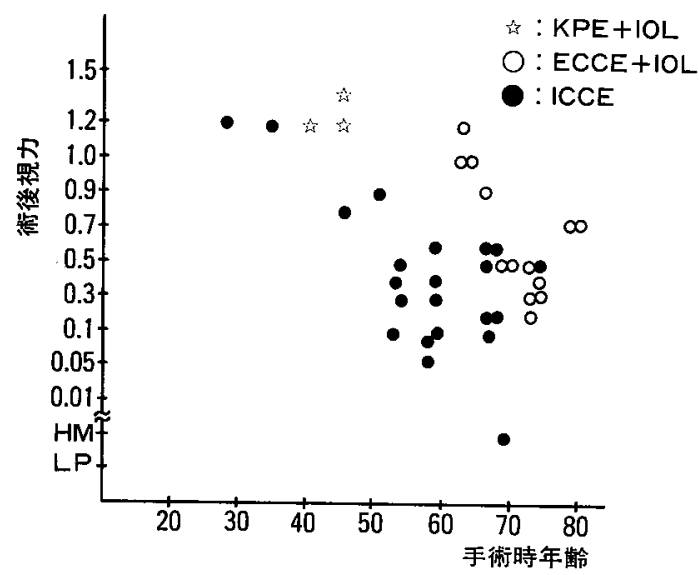

図 2 手術時年齢と術後視力

$\mathrm{KPE}$ : 超音波水晶体乳化吸引術 $\mathrm{ECCE}$ : 水晶体囊外摘 出術 ICCE : 水晶体囊内摘出術 IOL：眼内レンズ

表 1 透析患者の術前血液生化学所見

\begin{tabular}{l|l|l}
\hline & \multicolumn{1}{|c}{ 今回の症例 } & \multicolumn{1}{|c}{ 伊東 $^{21}$ の症例 } \\
\hline 赤血球数 & $230 \sim 404 \times 10^{4} / \mu l$ & $\left(230 \sim 404 \times 10^{4} / \mu l\right)$ \\
白血球数 & $4900 \sim 8700 \mathrm{~mm}^{2}$ & $\left(3100 \sim 9100 \mathrm{~mm}^{2}\right)$ \\
$\mathrm{Hb}$ & $7.1 \sim 9.8 \mathrm{~g} / \mathrm{d} l$ & $(8.5 \sim 14.4 \mathrm{~g} / \mathrm{d} l)$ \\
$\mathrm{Ht}$ & $22.0 \sim 30.8 \%$ & $(26 \sim 44 \%)$ \\
$\mathrm{Na}$ & $129 \sim 141 \mathrm{mEq} / l$ & $(136 \sim 144 \mathrm{mEq} / l)$ \\
$\mathrm{K}$ & $3.4 \sim 5.8 \mathrm{mEq} / l$ & $(4.1 \sim 5.9 \mathrm{mEq} / l)$ \\
$\mathrm{Ca}$ & $4.0 \sim 11.0 \mathrm{mEq} / l$ & $(3.7 \sim 8.6 \mathrm{mEq} / l)$ \\
$\mathrm{BUN}$ & $39 \sim 69 \mathrm{mg} / \mathrm{d} l$ & $(16 \sim 93.6 \mathrm{mg} / \mathrm{d} l$ \\
血清クレアチニン & $6.9 \sim 12.0 \mathrm{mg} / \mathrm{d} l$ & $(1.2 \sim 12.1 \mathrm{mg} / \mathrm{d} l)$ \\
\hline
\end{tabular}

の出血に関しては，非透析患者と比較して特に差は認め なかった。

術後視力は図 1 に示したごとく，全例改善した。視力 0.7 以上と末満にわけて, 検討してみると, 0.7 以上のも の 4 例 6 眼では眼底に特に著名な異常を認めなかった。 0.7 末満のもの 4 例 7 眼においてはなんらかの眼底変化 を認めた。一番視力の低い術後視力 0.15 の 1 例 1 眼を含 め 2 例 3 眼は, 糖尿病性網膜症を認め, 1 例 2 眼は術前 より網脈絡膜萎縮があり術後視力は 0.5 と 0.4 で, 残り の術後視力 0.5 の 1 例 2 眼には, 黄斑部類囊胞浮腫を認 めた，類囊胞浮腫の 1 症例は透析患者であることがより 視力を低下させていると考えられた．術後視力と透析期 間及び術後視力と血液検査所見との間には特に相関を認 めなかった。

術中合併症は 1 例 2 眼に, チン氏帯の脆弱によると思 われる水晶体囊の脱臼を認めたが, 視力は 1.0 と 1.2 を 得て問題とならなかった。この例は透析期間 13 年で, 我々の症例の中で最も透析期間が長かった。

術後出血や続発性緑内障を来した例はなく, 術後炎症 
及び切開創の治療経過に関しても非透析者と比較して大 きな差は認めなかった。

\section{考案}

白内障手術手技は，現在大きな転換期にきており計画 的水晶体囊外摘出術が, 水晶体全摘術に代わってその主 流を占めつつある。人エレンズに関してもその有用性が 認められ広く使われだしている，今回我々の検討した IOL 挿入透析患者 8 例 13 眼と当院の伊東ら ${ }^{2)}$ が過去に 報告した ICCE 施行透析患者 15 例 22 眼を比較した図を 図 2 に示す.

伊東ら ${ }^{2)}$ は全年齢層に ICCE を施行しているが，我久 は今回人エレンズ挿入の適応患者を 60 歳以上にしたた めこの年代群の伊東ら ${ }^{2)}$ の成績と比較すると, 我々の方 法の方が視力の改善がより良かった。合併症も伊東ら の ICCE では前房出血, 硝子体出血などをみとめたが 我々の方法では 1 例も出血例はなく, 従来の手術よりよ り安全な手術と考えた。

\section{結論}

血液透析患者の白内障に対する人工レンズ挿入術は， 従来の水晶体全摘出術に比較してょり安全な手術であっ
た. ICCE 法後の無水晶体眼者として不便を考え合わせ ると血液透析患者の白内障に対する人エレンズ挿入術は 推奨される手術法である.

\section{文献}

1) Berlyne GM Ari JB, Danovitch GM, Blumenthal $\mathrm{M}$ : Cataracts of chronic renal failure, Lancet i : 509-511, 1973

2) 伊東由紀子, 三宅養三：透析患者の白内障術後成績 についての観察, 眼臨 78:805-808, 1984

3）小暮美津子, 加藤昌久, 加藤有紀子, 鈴木利昭, 佐 中 孜, 太田和夫: 透析患者の白内障手術, 眼臨 $76: 1685-1689$

4）横田章夫, 平岡利彦, 松村 明, 小暮文雄: 透析患 者における白内障手術について, 臨眼 37 :412-416, 1983

5) Norman S J : In "Cataracta surgery and its comlications", p 33-245 Catavacta surgery and special techniques, C. V. Mosby Company Saint Louis, 1984 